\title{
A Research Review on Use of Micronutrient in Fruit Crops
}

\author{
Karuna Shanker $^{1 *}$, Sanyat Misra ${ }^{1}$, Mukesh Topwal ${ }^{2}$ and Varun Kumar Singh ${ }^{3}$ \\ ${ }^{1}$ Department of Horticulture, Birsa Agricultural University, Kanke- 834 006, Ranchi, \\ Jharkhand, India \\ ${ }^{2}$ Department of Vegetable Science, College of Agriculture, GB Pant University of Agriculture \\ and Technology, Pantnagar- 263 145, US Nagar, Uttarakhand, India \\ ${ }^{3}$ Savannah Seeds Pvt ltd. Lucknow- 226001 , India \\ *Corresponding author:
}

\section{Keywords}

Micro Nutrient, Growth, Yield, quality and Shelf life of fruit

Article Info

Accepted:

22 July 2019

Available Online:

10 August 2019

\section{A B S T R A C T}

Fruit Crops yield and quality significantly increase with the use of micronutrients such as zinc $(\mathrm{Zn})$, iron (Fe), Calcium (Ca) Magnesium ( $\mathrm{Mg}$ ) Boron (B), Copper (Cu), Manganese $(\mathrm{Mn})$, etc. Zinc $(\mathrm{Zn})$ has an important metabolically role in plants vegetative and reproductive phases; growth and development; is therefore called an essential trace element or a micronutrient. Calcium plays a critical role for the growth of fruit quality; while magnesium is an important component for chlorophyll and Iron involved in chlorophyll production; Boron for proper flower development and pollen germination; Copper and Manganese both helps in photosynthesis process and $\mathrm{Mg}$ also helps in nitrogen metabolism of carbohydrates and proteins and respiration. Micronutrient influences the activity of many metabolic enzymes, as well as the metabolism of several hormones. They are important co-factors found in the structure of certain enzyme and hormones. Use of micronutrients in fruit crops is an important management practice where much misinformation exists, by doing so, you can prevent deficiencies of micronutrients before they occur and reduce inefficient use of applied micro nutrients. There is so many research reviews indicated that the necessity and management of micro nutrients in fruit crops for better growth of vegetative, reproductive and physiological parameters. The aim of this review paper is to know the use of micronutrient in various fruit crops for growth, yield, quality and better shelf life. Also provide a ready source of literature review for researchers involved in Horticultural as well as agricultural sciences.

\section{Introduction}

Micronutrient deficiency is severing problem in soil and plants worldwide (Imtiaz, et al., 2010) while appropriate quality of micronutrients is necessary for better growth, better flowering, higher fruit set, higher yield, quality and post-harvest life of horticultural products (Ram and Bose, 2000; Raja, 2009, Sourour et al., 2000; Shekhar et al., 2010) while its deficiency leads in lowering the productivity (Zagade, 2017). Beside major plant nutrients there is eight essential nutrients which is required by plants in very 
small quantity, known as micronutrients viz., copper $(\mathrm{Cu})$, iron $(\mathrm{Fe})$, manganese $(\mathrm{Mn})$, molybdenum (Mo), nickel (Ni), zinc ( $\mathrm{Zn})$, boron (B), and chlorine $(\mathrm{Cl})$. Still, other elements like selenium ( $\mathrm{Se})$, silicon $(\mathrm{Si})$, and sodium $(\mathrm{Na})$ are regarded as nonessential, although they have been found to enhance growth and confirm other benefits to plants (Datnoff et al., 2007; Marschner 2012). Dependent on the enzyme, $\mathrm{Fe}, \mathrm{Mn}, \mathrm{Zn}, \mathrm{Cu}$, $\mathrm{Ni}, \mathrm{Mo}$, and $\mathrm{Cl}$ all participate in the functioning of different enzymes, including DNA/RNA polymerases, N-metabolizing enzymes, superoxide dismutases, catalases, dehydrogenases, oxidases, ATPases and numerous other enzymes involved in redox processes (Broadley et al., 2012). Boron is important micro nutrient required for good quality and high yield of crops (Dale and Krystyna, 1998, Mahmoud M. Shaaban 2010). It involved in the synthesis and integrity of cell wall, cell wall lignification, metabolism of RNA, carbohydrate, phenol and Indole Accetic Acid (IAA), respiration and cell membrane integrity (Parr and Loughman, 1983). Boron is exclusive as a substance in this the brink between deficiency and toxicity is narrows (Mortvedt et al., 1991). Boron Deficiency found to affect plant growth and reduced yield (Dell and Huang, 1997, Carpena et al., 2000) better growth and yield was obtained when crops were supplied with Boron (Oyinlola, 2005, Shaaban et al., 2004). Single foliar boron application is effective in increasing $\mathrm{B}$ concentration in flower buds, higher B concentrations, however, can improve fruit set in sweet cherry, so the possible positive effects can easily cover the costs. Nutrition with boron can be more useful especially when fruit set is low and can be in function of controlling tree vigor (Valentina Usenik and Franci Stampar, 2007). Flower clusters have a high demand for boron (B) during blossoming if fruit set is to be fully effective (Hanson and Proebsling, 1996). Application of B sprays is often used to ensure that sufficient amounts of B are available for flower fertilization, fruit set, and early fruit let development (Peryea, 1992; Zude et al., 1998; Hanson et al., 1985; Stover et al., 1999; Nyomora et al., 1999; Štampar et al., 1999; Solar et al., 2001). Flower buds are a preferential sink for B mobilization after foliar application (Sanches and Righetti, 2005). Zinc ( $\mathrm{Zn}$ ) is another important essential micronutrient which helps in the formation of tryptophan, a precursor of IAA responsible for growth stimulation (Mallick and Muthukrishnan, 1979) and plays a vital role in synthesis of carbonic anhydrase enzyme which helps in transport of $\mathrm{CO}_{2}$ in photosynthesis (Alloway, 2008) and directly or indirectly required by several enzyme systems and synthesis of auxin. Magnesium is the metallic constituent of chlorophyll and regulates the uptake of other nutrients (Ram and Bose, 2000). Iron increases photosynthesis and carbohydrate synthesis and in reproductive growth of fruit in organs of the plant acts as a strong sink (Sohrab et al., 2013).

The nutrients required in large quantity are supplied through soil application (Fageria et al., 2009) but nutrients needed in lower quantity can be better absorbed through foliar spray (Fageria et al., 2009; Girma et al., 2007). Best timing for foliar sprays should be one or more of the followings; i) at a new flush, ii) after fruit harvesting, iii) preanthesis/2-3 weeks prior to fruit bud differentiation, iv) at full bloom, and v) at the small fruit formation stage. Due to restricted mobility of iron, zinc and boron in plant tissues and keeping in view plant physiology, the authors are of the view that as orchard crops try to accumulate maximum amounts of essential nutrients before flower formation so micronutrients foliar sprays should be made preferably after fruit harvest and before flower formation in addition to recommended deficiency doses already applied through soil. 
Foliar sprays can prevent or correct a problem with relatively small amounts absorbed by the foliage but at the same time, it has also been recognized that root uptake must be maximized in order to obtain the most benefit from foliar sprays. For details about different aspects of foliar nutrition, readers may refer to various reviews (Haynes and Goh, 1977; Slowik and Swietlik, 1978; Kannan, 1980). Mineral nutrients enter into leaves in three steps (Frank, 1967) involving: (1) penetration through the cuticle and epidermal walls; (2) adsorption on the surface of the plasma lemma, and (3) passage through the plasma lemma into the cytoplasm. Discontinuities and cracks in the epicuticular waxes, however, open a pathway for penetration of leaf-applied nutrients. Encouraging Reviews of micronutrient application on growth, yield and quality of various fruits crops have been reported by the earlier researcher. Micronutrient deficiency found to affect plant growth and reduced yield of fruit crops. The main objective of this paper to review different hypothesis and experimental results on micronutrient functions.

\section{Major Response of micronutrient in fruit crops}

\section{Response of micro nutrient on Vegetative growth of fruit crops}

Many reports have shown higher vegetative growth when applied the micronutrients in fruit crops. John Wooldridge, 2002 tested that under trace element-deficient, pot trial conditions over a 21-month, post-planting period, a combination of fritted trace element carrier, mixed into the sand soil at the rate of $100 \mathrm{gm}^{3}$ before planting, followed by a program of alternating $\mathrm{Mn}+\mathrm{Zn}$ and $\mathrm{B}+\mathrm{Cu}$ foliar sprays, promoted improved vegetative growth in nursery-grown Braestar/M793 apple trees. Similarly trees Dawood et al., 2001 confirm that foliar application of $\mathrm{Zn}$ increases vegetative growth of young sweet orange. Singh et al., (2005) reported that use of micro nutrients (Boron and Zinc) as Borax and Zinc sulphate $(0.25$ and 0.50 percent respectively) increased plant growth when they are applied in combination or alone in papaya cv. Ranchi. Rajaie, M. et al., 2009 studied the impact of different concentration of zinc ( $\mathrm{Zn}$ ) and boron (B) on growth and mineral composition of lemon seedlings (Citrus Aurantifolia L.) he found that the Fresh and dry plant weights of the control treatment were strongly decreased with B levels higher than $5 \mu \mathrm{g}$ g-1 of soil. $\mathrm{Zn}$ treatments reduced $\mathrm{B}$ accumulation and the associated inhibitory effect on plant growth. Increased B level in soils enhanced the concentration of $\mathrm{B}$ in plant shoots to a greater extent in the absence of applied $\mathrm{Zn}$. The best plant production was achieved when 2.5 and $10 \mu \mathrm{g}$ g-1 soil of $\mathrm{B}$ and $\mathrm{Zn}$ were applied simultaneously. This combination was associated with the highest uptake of $\mathrm{Zn}$, nitrogen $(\mathrm{N})$, phosphorous $(\mathrm{P})$, potassium $(\mathrm{K})$, iron $(\mathrm{Fe})$, manganese $(\mathrm{Mn})$ and copper $(\mathrm{Cu})$, suggesting that the combination resulted to a suitable condition in which plants had a wellbalanced nutritional status. Jasrotia, et al., (2014) found that the foliar Application of Zinc $(0.6 \%$ ZnSo4) in Combination with Boron $(0.6 \%$ Boric Acid) resulted in the significantly influenced the shoot extension growth and chlorophyll content in the olive leaf while Razzaq, K. et al., 2013 found that the foliar application of $\mathrm{Zn}$ as $0.6 \%$ zinc sulfate had a positive effect on vegetative and reproductive growth in 'Kinnow' mandarin.

Response of micro nutrient on initial fruit set $(\%)$, fruit retention (\%) and fruit drop $(\%)$

Many review reports have indicated that significant effect of micronutrients on initial fruit set, fruit retention, and fruit drop. Singh and Vashistha (1997) advocated that 
application of $0.5 \%$ borax $\left(\mathrm{Na}_{2} \mathrm{~B}_{4} \mathrm{O}_{7} \cdot 10 \mathrm{H}_{2} \mathrm{O}\right)$ and $0.5 \%$ zinc sulphate was obtained most effective to minimize fruit drop percentage in ber $c v$. Seb. Banik et al., (1997) noted that foliar application of Zinc, Iron and Boron each at $0.1,0.2$ and 0.4 percent respectively, significantly influenced the flowering and fruiting of 13-year-old mango $c v$. Fazli. Kundu and Mitra (1999) observed foliar application of $1.0 \%$ borax 0.3 percent copper influenced the fruit set $(\%)$ and hastened the fruit ripening. Sinha et al., (1999) reported foliar application of $0.1 \%$ borax and $0.8 \%$ zinc sulphate reduced the fruit drops and increased the fruit retention (\%) in Litchi cv. Purbi. Ali et al., (1991) reported that spraying of nutrients \& their combination at urea 2 percent, potassium sulphate $1 \%$, zinc sulphate 0.4 percent, and borax 0.2 percent were found effective to increase the yield per tree in guava cv. Allahabad safeda. Kamble et al., (1994) stated that foliar spray of Iron, Manganese, Zinc, and Boron increased percent fruit set and fruit retention in ber $(Z$. mauritiana Lamk.) cv. Banarasi karaka. Razzaq, K. et al., 2013 found that the foliar application of zinc sulfate significantly increased number of fruits and fruit weight in 'Kinnow' mandarin. Similar results have been reported by Shawky et al., (1990) and Ismail (1994) who found that foliar application of $\mathrm{Zn}$ increased the yield of 'Navel' and 'Valencia' oranges. Application of $\mathrm{B}$ prior to flowering increased fruit set of olive 'Manzanillo' (Perica et al., 2001). Boron sprays after bloom increased fruit set and yield of the apple cultivar 'Elstar' (Wojcik et al., 1999) and sprays at the pink flowering stage increased flower cluster and early-season leaf B concentrations of the apple 'Scarlet Gala' (Peryea et al., 2003). Foliar applications of B before full bloom or after harvest increased fruit set and fruit yield of 'Conference' pear (Wojcik and Wojcik, 2003). Das et al., (2000) reported the effect of foliar spray of zinc sulfate $(0.5$ or $1.0 \%)$ aqueous solution at 25 -
27 days after fruit set on the fruit quality of guava cv. 'Allahabad Safeda'. Fruits were analyzed 15, 54 and 93 days after spraying resulted in both zinc sulfate concentrations increased the total, reducing and non-reducing sugar content of fruits. Greater increase, however, were recorded for $1.0 \%$. They also recorded fruit sweetness due to zinc sulphate starter 15 days spraying when the fruits were in the early development stage. Sharma et al., (2002) reported that combination application of 0.50 per cent $\mathrm{ZnSO} 4$ and 20 ppm 2,4-5T on 10 years old Kagzi lime ( $C$. aurantifolia) resulted in the highest fresh weight $(51.84 \mathrm{~g})$, volume of fruit $(44.60 \mathrm{ml})$, number of seeds per fruit (15.05), acidity (9.20\%), ascorbic acid content (49.83 mg/100 ml juice) and TSS $(10.18 \%)$, whereas, combined application of $0.50 \%$ zinc sulphate and 50 pm GA3 resulted in the highest juice content (57.36\%). Application of zinc at higher level increased the foliar zinc content which ultimately encourages the endogenous production of auxin thereby reducing fruit drop (Meena et al., 2014).

\section{The response of micronutrient on physical characters of fruits}

Singh et al., (1983) found that foliar spray of 3.0 percent urea and 0.3 percent boric acid increased the size of fruit in guava cv. Lucknow-49. Pandey et al., (1990) reported that in ber cv. Banarasi karaka, fruit weight and volume increased continuously throughout the development period and specific quality decrease markedly up to 45 days after fruit setting and then stabilized until harvest. Sarangi et al., (1992) advocated that in case of Cape gooseberry both weight and volume increased with an increasing number of days from fruit set. Chaitanya et al., (1997) reported that foliar feeding of 0.3 per cent zinc sulphate and above increased the length and diameter of fruit in guava cv. Lucknow-49. Rao et al., (2004) spraying 
$\mathrm{K}_{2} \mathrm{SO}_{4}(2.0 \%)$ and $\mathrm{ZnSO}_{4}(0.4 \%)$ at the time of fruit setting stage proved most effective in reducing fruit drop and increasing yield in ber cv. Banarasi karaka. Jay Kumar et al., (2008) observed that the use of micronutrients Zinc and Boron as a foliar spray as well as soil application on 4 and 8 months after planting increased plant growth in Papaya cv. Coimbatore- 6. Meena et al., (2008) reported that the application of $\mathrm{FeSO}_{4}$ and borax at par stage@ @ $0.6 \%$ produced maximum average fruit weight, pulp weight stone weight pulp stone ratio and yield. Zhang Cheng Hao Lim (2010) reported that the combined spraying of borax $0.1 \%$ along with $\mathrm{ZnSO}_{4} 0.003 \%$ and phosphorus $0.6 \%$ in paprika (Capsicum annum L.) increased the fruit size and weight. In apples pink flowering timing for B, sprays are often used because of the importance of adequate B for proper pollen tube growth; flower fertilization, fruit set, and early fruit let development (Peryea, 2002).

\section{The response of micronutrient on the yield of fruits}

Ingle et al., in 1993 reported the use of Borax 0.2 percent and Zinc sulphate 0.4 per cent as foliar spray increase fruit yield in Guava cv. Lucknow- 49 and Chaitanya et al., (1997) also confirm the same. Kundu and Mitra (1999) also confirm that foliar application of 1.0 per cent borax and 0.3 per cent zinc sulphate 0.3 per cent copper increased the fruit yield in guava. Panwar et al., (1994) noted that foliar spray of Borax 0.1 per cent significantly increased the yield of aonla cv. Banarsi. Stampar et al., (1999) advocated that foliar application of borax, zinc and phosphorus ( 0.2 per cent), increased the yield up to 30 per cent in apple. Rao et al., (2004) reported that the application of potassium sulphate $(2.0 \%)$ and zinc sulphate $(0.4 \%)$ with a concentration of 200 ppm NAA increasing fruit yield in ber cv. Banarasi karaka. Meena et al., (2008) reported that the application of borax and ferrous sulphate @ 0.6\% produced the high yield in ber cv. Gola. Jafarpour and Poursakhi 2011 revealed that the positive effect of foliar application in spring and fall on the yield increase was superior to the control, but the highest yield was obtained in the foliar application in the fall+ spring. In spite of the increased yield through localized fertilization treatment and foliar application in the fall+ spring, no decrease was observed in fruit texture firmness. However, the specific weight of fruits and the TSS/TA ratio were increased. Sajid et al 2010 revealed that the foliar application of zinc in combination with boron may be applied in order to increase the production and to control the decline of a citrus orchard in order to get high-quality fruit Production, yield and extend the bearing life of citrus plants. Mustafa et al., 2013 revealed that application of $25 \mathrm{~kg}$ F.Y.M.+ $1 / 2 \mathrm{NPK}+$ $\mathrm{ZnSO}_{4} \quad+\mathrm{CuSO}_{4}+\mathrm{FeSO}_{4}$ (T4) produced maximum fruit yield and fruit size as well as nutrient content in aonla. Mirzapour and Khoshgoftarmanesh (2013) study the performed to investigate the effectiveness of soil and foliar application of iron $(\mathrm{Fe})$ and zinc (Zn) fertilizer on pomegranate (Punica granatum L cv. 'Ghojagh') in a calcareous soil. Results were reviled soil application of FeEDDHA and ZnSO4.7H2O, particularly as localized placement, is an appropriate and effective approach to improve the yield and fruit quality of pomegranate in the calcareous soils. Razzaq, K. et al., 2013 found that the foliar application of zinc sulfate significantly increased yield in 'Kinnow' mandarin. The increase in fruit weight, size and peel thickness of 'Kinnow' mandarin fruit with foliar application of $\mathrm{Zn}$ might be associated with the role of Zinc in the synthesis of tryptophan, a precursor for the synthesis of indoleacetic acid (Cakmak et al., 1989). These results confirm the previous findings of Sahota and Arora in 1981 who stated that foliar application of $\mathrm{Zn}$ increased the fruit yield by increase in fruit weight and size in 
sweet orange. Eman et al., (2007) also reported that $\mathrm{Zn}$ spray increased the peel thickness in 'Washington Navel' oranges.

\section{The response of micronutrient on Quality characters of fruits}

Ahlawat and Yamdogni (1981) to narrate that the seven spray of potassium sulphate at $1 \%$ increased the percentage of total sugar in the fruit of guava cv. Safeda. Singh et al., (1983) reported that foliar spray of $0.3 \%$ borax along with $3.0 \%$ urea increased the total soluble solids (T.S.S.) and sugar content in guava cv. Lucknow-49. Brahmachari and Kumar (1997) observed that foliar spray of 1.0 per cent zinc sulphate, 0.4 per cent borax and 2 per cent calcium nitrate increased the T.S.S. and ascorbic acid content in Litchi fruit. Kundu and Mitra (1999) reported that foliar application of 0.3 per cent copper 0.1 per cent borax and 0.3 per cent zinc the T.S.S. ascorbic acid, total sugar in lemon. Singh et al., (2007) found out the application of borax $(0.2 \%)$, zinc sulphate $(0.6 \%)$ on aonla and found that zinc at $0.6 \%$ was most effective in increasing the T.S.S. ascorbic acid content. Meena et al., (2008) observed that application of ferrous sulphate and borax at $(0.6 \%)$ fruit setting time increased the T.S.S. and total sugar and decreased the acidity content in ber fruit cv. Gola. (Maribela Pestana, et al., 2001) evaluated that the concentrations of phosphorous (P) and magnesium $(\mathrm{Mg})$ in flowers were correlated with those in leaves, and were also predictive of the chlorophyll content of leaves 60 days later. However, by 120 days after full bloom, these effects were masked, possibly by a fertilizer application carried out by the farmer. The iron $(\mathrm{Fe})$ concentration in flowers was correlated with chlorophyll measured either 60 or 120 days after full bloom. These parameters can, therefore, be used to predict the appearance of iron chlorosis. Fresh weight and diameter of fruit were related to flower $\mathrm{P}, \mathrm{Mg}$, and manganese $(\mathrm{Mn})$ concentrations, while the percentage of citric acid in the fruit juice was inversely correlated with $\mathrm{Fe}$ flower concentrations. Hasani, M. et al., 2012 examine the response of foliar spray of zinc and manganese sulfates on the fruit yield and quality as well as leaf nutrients concentration of pomegranate, he observed that the $\mathrm{Mn}$ sprays had positive significant effects on the fruit yield, the aril/peel ratio, TSS, weight of 100 arils, juice content of arils, anthocyanin index, fruit diameter, and leaf area. $\mathrm{Zn}$ effects were also significant for TSS, TSS/TA ratio, juice content of arils and leaf area. Foliar spray of Mn significantly increased $\mathrm{Mn}$ and $\mathrm{N}$ but decreased $\mathrm{Zn}$ and $\mathrm{Cu}$ concentrations in leaves. Foliar sprays of $\mathrm{Zn}$ significantly increased $\mathrm{Zn}$ but decreased $\mathrm{Mn}$ and $\mathrm{P}$ concentrations in the leaves. Shad Khan Khalil et al., 2011 reported that B is important for the sufficient quantity needed for the proper growth, development, fertilization growth, and nut yield and nut quality in pecan. Wojcik and Wojcik 2006 examine response of sweet cherries (Prunus avium L.) to boron (B) fertilization, result was found that $\mathrm{B}$ fertilization had no effect on vigour and yield of sweet cherry trees despite increased concentration of this microelement in flower and leaf tissues. Mean fruit weight, titratable acidity, and fruit sensitivity to cracking also were not influenced by B fertilization. Pawel Wojcik 2005 results obtained showed that soil or foliar application of $B$ did not affect vigour and yield of 'Bluecrop' high bush blueberries grown on coarse-textured soil poor in water-soluble Boron. Saadati et al., 2013 reported that foliar application of zinc sulphate, boric acid, and their combination significantly promoted soluble sugar and oil contents of olive fruits. Results showed that utilization of microelements such as B and Zn were capable to enhance both the quantity and quality of oil content such as oleic acid and phenolic compounds in olive fruits in semiarid areas. 
Jasrotia et al., (2014) found that the foliar Application of Zinc $(0.6 \%$ ZnSo4) in Combination with Boron $(0.6 \%$ Boric Acid $)$ resulted in the significantly influenced Fruit Size, Fruit weight and Volume, Pulp: Stone Ratio and oil content in olive cv. Frontoio. Razzaq et al., 2013 found that the foliar application of zinc sulfate significantly influenced physical and chemical fruit quality characteristics in 'Kinnow' mandarin. Chandler. Waskela et al., (2013) reported that, the maximum weight (187.18 g), length $(7.06 \mathrm{~cm})$ and width $(7.09 \mathrm{~cm})$, high pulp (96.91\%), pulp: seed ratio (32.09), of fruit was obtained with the foliar application of $0.75 \%$ zinc sulphate in guava cv. Dharidar.

\section{The response of micronutrient on the shelf life of fruit}

Gupta et al., (1989) to informed that $6.7 \%$ pathological weight loss after room condition and Gupta and Mehta (1998) reported that untreated fruits of ber cv. Gola can be stored for 12-15 days with 7.64 percent weight loss whereas kathali cultivar of ber can be stored for 8-9 day with about 15 per cent weight loss. Usha and B.K. Singh (2002) reported that the effect of foliar spray of Iron (Fe at $0.2 \%$ ) and boron (Bat $0.4 \%$ ), magnesium (mg at $0.02 \%$ ) improved the quality of grape cv. perlette significantly increased in the berry weight. Singh et al., (2007) the application of potassium sulphate 0.6 per cent borax $(1.3 \%)$ was most effective in increasing the T.S.S. ascorbic acid content and shelf life. Yadav and Sharma (2009) reported that sprayed of 10 days intervals, $\mathrm{K}_{2} \mathrm{SO}_{4} 1.5 \%$ or $2.0 \%$ on the ber fruit cultivar Umran increasing the T.S.S. total sugar and observed the acidity content decreased the lowest acidity was found in 15 days of storage. Jawandha et al., (2009) reported that the effect of Boran $(0.1 \%)$ with $\mathrm{CaCl}_{2} \quad(2 \%)$ pre-harvest application maintained very good fruit quality and prolonged shelf life for 20 days under open storage conditions. Zhang Lim Yong Sup (2010) informed that the application nutrient solution (B-3.5\% + CU- $0.0005 \%+\mathrm{mg}-3.5 \%$ $+\mathrm{P}-6 \%$ ) in ber fruit increasing the quality of ber fruit, T.S.S. and Shelf life also and enhanced the acidity ascorbic acid. Mishra et al., 2017 observed that the foliar application of $\mathrm{CuSO}_{4}(0.4 \%)+\mathrm{MnSO}_{4}(0.5 \%)+\mathrm{ZnSO}_{4}$ $(0.4 \%)$ obtained the maximum fruit yield and better quality of Aonla fruits.

In conclusion, from the above mentioned reviewed it is concluded that the role of micronutrient have a significant effect on fruit plants and significantly improves the vegetative growth, fruit yield, quality and shelf life of fruit crops. Use of micronutrients will continue to increase in the near future and depending primarily upon the economic benefits.

\section{References}

Ahlawat, V.P., Sharma, S., Dahiya, S.S. and Yamdagni, R. 1985. Effect of urea sprays on physic-chemical characteristics of grapes $(V$. Vinifera $\mathrm{L}$.) cv. beauty seedless. Prog. Hort., 17(2): 100-102.

Ali, W., Pathak, R.A. and Yadav, A. L. 1991. Effect of foliar application of nutrients on guava cv. Allahabad Safeda. Prog. Hort. 23(1-4): 18-31.

Alloway, B. J. 2008. Zinc in soils and crop nutrition. Paris, France: IFA; and Brussels, Belgium: IZA.

Banik, B.C., Mitra, S.K., Sen, S.K. and Bose, T.K. 1997. Effect of zinc boron and iron spray on the physico-chemical composition of mango cv. Fazli. The Orissa J. Hort., 25 (1-2): 78-80.

Brahmachari, V. S. and Kumar, R. 1997. Effect of foliar application of nutrients on fruit set retention and cracking of litchi (Litchi chinensis Sonn.) fruits. Haryana J. Hort. Sci., 26 (3-4): 177-180

Broadley, M., Brown, P., Cakmak, I., Rengel, Z. and Zhao, F. 2012. Functions of nutrient: micronutrients. In: Marschner P 
(ed) Marschner's mineral nutrition of higher plants, 3rd edn. Elsevier, Oxford, pp 243-248.

Cakmak, I., Marschner, H. and F. Bangerth. 1989. Effect of zinc nutrition status on growth, protein metabolism and level of indole-3 acetic acid and other phytohormones in bean (Phaseolus vulgaris L.). Journal of Experimental Botany 40: 405-415.

Carpen, R.O., E. Esteban, M., Jose, S., Penallosa, J., Garate, A., Lucena, J. and Zornoza, P. 2000. Boron and calcium distribution in nitrogen fixing pea plants. Plant Sci., 151:163-170.

Chaitanya, C.G., Kumar, G., Rana, B.L. and Muthoo, A.K. 1997. Effect of foliar application of zinc and boron on yield and quality of guava cv. L. 49. Haryana $J$. Hort. Sci., 26 (1-2): 78-80.

Dale, G.B. and Krystyna, M. L. 1998. Boron in plant structure and function. Annu. Rev. Plant Physiol. Plant Mol. Biol. 49: 481500.

Das, A., Majumdar, K. and Mazumdar, B.C. 2000. Zinc sulphate induced higher sweetness of rainy season guava fruits. Indian Agriculturist, 44(3-4):199-201.

Datnoff, L. E., Elmer, W. H., Huber, D. M. 2007. Mineral nutrition and plant disease. The American Phytopathological Society, St. Paul.

Dawood, S. A., Meligy, M. S. and El-Hamady, M. M. 2001. Influence of zinc sulfate application on tree leaf and fruit characters of three young citrus varieties grown on slightly alkaline soil. Annals of Agriculture Science Moshtohor 39: 433-447.

Dell, B. and L. Huang. 1997. Physiological response of plant to boron. J. plant soil. 193:103-120.

Eman, A. A., El-Moneim, A., Abd El-Migeed, M. M. M., Omayma, A. and Ismail, M. M. 2007. $\mathrm{GA}_{3}$ and zinc sprays for improving yield and fruit quality of Washington Navel orange trees grown under sandy soil conditions. Research Journal of Agricultural and Biological Sciences 3: 498-503.
Fageria, N. K., Filho, M. P. B., Moreira, A. and Guimaraes, C. M. 2009. Foliar fertilization of crop. plants. J. Plant Nutr. 32: 10441064.

Franke, W. 1967. Mechanism of foliar penetration of solutions. Annual Reviews Plant Physiology 18: 281-300.

Girma, K., Martin, K. L., Freeman, K. W., Mosali, J., Teal, R. K., Raun, W. R., Moges, S. M. and Arnall, D. B. 2007. Determination of optimum rate and growth for foliar applied phosphorus in corn. Comm. Soil Sci. Plant Anal. 38: 11371154.

Gupta, O.P. and Mehta, N. 1998. Effect of pre harvest application of chemicals on the shelf-life of ver fruits cv. Gola. Haryana $J$. Hort. Sci., 17 (3-4): 183-189.

Gupta, O. P., Siddique, S. and Gupta, A.K. 1989. Effect of pre-harvest spray of various chemical on the storage of ver fruits $(Z$. mauritiana Lamk.) Res. Dev. Report, 6 (1): 35-40.

Hanson, E. J., Chaplin, M. H. and Breen, P. J. 1985. Movement of foliarly applied boron out of leaves and accumulation in flower buds and flower parts of 'Italian' prune. Hort Science 20: 747.

Hanson, E. J. and Proebsling, E. L. 1996. Cherry nutrient requirements and water relations. In: A. D. Webster and N. E. Looney (eds.), Cherries: crop physiology, production and uses', CAB International, Wallingford, UK: 243-257.

Hasani, M., Zamani, Z., Savaghebi, G. and Fatahi, R. 2012. Effects of zinc and manganese as foliar spray on pomegranate yield, fruit quality and leaf minerals Journal of Soil Science and Plant Nutrition, 12 (3), 471-480.

Haynes, R. J. and K. M. Goh. 1977. Review on physiological pathways of foliar absorption. Scientia Horticulturia 7: 29102

Imtiaz, M., Rashid, A., Khan, P., Memon, M. Y. and Aslam, M. 2010. The Role of Micronutrients in Crop Production and Human Health. Pak. J. Bot., 42(4): 25652578 . 
Ingle, K.G., Khan, M.A.H. and Kshirsagar, R.E. 1993. Effect of foliar application of nutrients on yield and quality of guava. Environ. Eco., 23 (1): 53-55.

Ismail, A. I. 1994. Growth and productivity of Valencia orange trees as affected by micronutrients applications. Ph.D Thesis, Faculty of Agriculture, Cairo University, Cairo, Egypt.

Jafarpour, M. and Poursakhi, K. 2011. Study of concurrent effect of using nutrients through soil and foliar application on yield and quality of the "Red Delicious" apple. International Conference on Life Science and Technology. IPCBEE vol.3 IACSIT Press, Singapore.

Jasrotia, A., Bakshi, P., Wali, V. K., Bhushan, B. and Bhat, D. Ji. 2014. Influence of girdling and zinc and boron application on growth, quality and leaf nutrient status of olive cv.frontoio. African journal of agricultural research 9(18) 1355-1361.

Jawandha, S. K., Mahajan, B. V. C. and Gill, P. S. 2009. Effect of pre-harvest treatments on the quality and shelf life of ver fruit cv. Umran under storage conditions. Notulae Scientia Biological. 1:1, 88-91.

Jay Kumar, P., Durgadevi, D. and Kumar, N. 2008. The response of Papaya Plant to foliar application of micronutrients. Development in Plant Science, 42: 23-27.

John Wooldridge. 2002. Effect of Trace Element Sprays And Fritted Trace Elements On The Growth And Manganese, Zinc, Copper, And Boron Contents of Young Braestar/M793 Apple Trees In Sand culture, Journal of plant nutrition, 25(1): 43-59.

Kamble, A. B., Desai, U. T. and Chaudhari, S. M. 1994. Effect of micronutrients on fruit set; fruit retention and yield of ber (Zizyphus mauritiana L) cv. Banarsi Karaka. Annuals of Arid Zone, 33 (1): 5355.

Kannan, S. 1980. Mechanism of foliar uptake of plant nutrients: accomplishments and prospects. Journal of Plant Nutrition 2: 717- 35.

Kundu, S. and Mitra, S. K. 1999. The response of foliar spray of copper, boron, and zinc on quality of guava. Indian Agric., 43 (12): $49-52$

Mahmoud M. Shaaban. 2010. Role of boron in plant nutrition and human health. American journal of plant physiology, 5(5): 224-240.

Mallick, M. F. R. and Muthukrishnan, C. R. 1980. Effect of micro nutrients on tomato (Lycopersicon esculentum Mill.), Effect on flowering, fruit-set and yield. South Indian Hort. 28 (1): 14-20.

Maribela Pestana., Pedro Jose Correia; Amarilis de Varennes; Javier Abad. and Eugenio Arau jo Faria. 2001. The use of floral analysis to diagnose the nutritional status of orange trees Journal of Plant Nutrition, 24(12): 1913-1923.

Marschner, P. 2012. Marschner's mineral nutrition of higher plants, 3rd edn. Elsevier, Oxford.

Mustafa, Md., Pandey, S. K., Katare, S., Pandey, D. and Singh, A. 2013. Response of integrated nutrient management in aonla (Embalica officinalis Gaertn) under medium black soil, Progressive Horticulture 45 (2): 285-287.

Meena, V. S., Yadav, P. K. and Meena, P. K. 2008. Yield attributes of ver (Zizyphus Mauritania Lamk.) cv. Gola as influenced by foliar application of ferrous sulphate and boron. Agri., Sci., Digest., 28:3.

Meena, D., Tiwari, R. and Singh, O. P. 2014. Effect of nutrient spray on growth, fruit yield and quality of aonla. Annals Plant and Soil Res., 16 (3): 242-245.

Mirzapour, M. H. and Khoshgoftarmanesh, M. H. 2013. Effect of soil and foliar application of iron and zinc on quantitative and qualitative yield of pomegranate Journal of Plant Nutrition, 36:55-66.

Mishra, S. M., Ram, D., Pandey, A. and Meena, A. K. 2017. Effect of Foliar Feeding of Micro-nutrients on Physico-Chemical Attributes of Aonla (Emblica officinalis Gaertn) cv. Na-7 Under High Density Planting. Int. J. Curr. Microbiol. App. Sci. 6(5): $\mathrm{xx}-\mathrm{xx}$.

Mortvedt, J. J., Cox, F. R., Shuman, L. M. and Welch, R. M. 1991. Micronutrients in 
agriculture. Second ed. SSSA Book Ser. 4. SSSA, Madison, WI.

Nyomora, A. M. S., Brown, P. H. and Krueger, B. 1999. Rate and time of boron application increase almond productivity and tissue boron concentration. HortScience 34: 242.

Oyinlola, E. Y. 2005 distribution of Boron and its Uptake in the plants parts of two tomato Varieties. Chem. Class J., 2:77-80.

Pandey, R. C., Pathak, R. A. and Pathak, R. K. 1990. Physico-chemical changes associated with growth and development of fruit in ver (Zizyphus mauritina Lamk.). Indian J. Hort., 47 (3): 286-290.

Parr, A. J. and Loughman, B. C. 1983. Boron and Membrane Function in Plants. In: Robb, D.A. and Pierpoint, W.S., Eds., Metals and Micronutrients, Uptake and Utilization by Plants, Academic Press, New York: 87-107.

Pawar, R. D., Saini, R. S., Koushik, R. A. and Yamdagni, R. 1994-95. Effect of micronutrients on fruit retention; yield and quality of aonla cv. Banarsi under rain fed condition, Haryana J. Hort. Sci., 22 (1-2): 250-251.

Pawel Wojcik. 2005. Response of 'Bluecrop' Highbush Blueberry to Boron Fertilization Journal of Plant Nutrition, 28: 1897-1906.

Perica, S., Brown, P.H., Connell, J. H., Nyomora, A. M. S., Dordas, C., Hu, H. N. and Stangoulis, J. 2001. Foliar boron application improves flower fertility and fruit set of olive. HortScience 36: 714.

Peryea, F. J. 1992. History of boron research in apples, pears reviewed. Good Fruit Grower. 43: 26-29.

Peryea, F. J. 2002. Properties and performance of boron spray products for apple. Proceedings of International Symposium on Foliar Nutrition. Acta Horticulture. 594: 211-214

Peryea, F. J., Neilsen, D. and Neilsen, G. 2003. Boron maintenance sprays for apple: Earlyseason applications and tank-mixing with calcium chloride. Hortscience. 38: 542.

Raja, E. M., 2009. Importance of micronutrients in the changing horticultural scenario. $J$.
Hort. Sci., 4 (1): 1-27.

Rajaie, M., Ejraie, A. K., Owliaie, H. R., Owliaie. and Tavakoli, A. R. 2009. Effect of zinc and boron interaction on growth and mineral composition of lemon seedlings in a calcareous soil International Journal of Plant Production. 3(1): 39-50.

Ram, R. A. and Bose, T. K. 2000. Effect of foliar application of magnesium and micronutrients on growth, yield and fruit quality of mandarin orange (Citrus reticulata Blanco). Indian Journal of Horticulture, 57(3): 215-220.

Rao, U. B., Shukla, H. S. and Verma, G. 2004. Effect of foliar application of potassium sulphate and zinc sulphate on fruiting and fruiting characteristics and of ver organized by C.S.A.U. \& T. Kanpur on February, 4 (6): 167-168.

Razzaq, K., Khan, A. S., Malik, A. U., Shahid, M. and Ullah, S. 2013. Foliar application of zinc influences the leaf mineral status, vegetative and reproductive growth, yield and fruit quality of 'kinnow' mandarin Journal of Plant Nutrition, 36:1479-1495.

Saadati, S., Moallemi, N., Mortazavi, S. M. H. and Seyyednejad, S. M. 2013. Effects of zinc and boron foliar application on soluble carbohydrateand oil contents of three olive cultivars during fruit ripening Scientia Horticulturae 164: 30-34.

Sahota, G. S., and J. S. Arora. 1981. Effect of N and $\mathrm{Zn}$ on 'Hamlin' Sweet orange. Journal of the Japanese Society for Horticultural Science. 50: 281-286.

Sajid, M., Rab, A., Ali, N., Arif, M., Ferguson, L. and Ahmed, M. 2010. Effect of foliar application of $\mathrm{Zn}$ and $\mathrm{B}$ on fruit production and physiological disorders in sweet orange cv. Blood orange. Sarhad J. Agric. 26(3): $355-360$.

Sanches, E. E. and Righetti, T. L. 2005. Effect of postharvest soil and foliar aplication of boron fertilizer on the partitioning of boron in apple trees. Hortscience. 40: 2115.

Sarangi, D., Sarkar, T. K., Ray, A. K., Jana, S. C. and Chattopadhyay, T. K. 1992. Physicochemical changes during growth of gooseberry fruit (Physalis peruviana L.) 
Prog., Hort., 21 (3-4): 225-228.

Shaaban, M. M., El- Fouly, M. M. and AbdelMaguid, A. A. 2004. Zinc- Boron relationship in wheat plants under low or high level of calcium carbonate in the soil. Pakistan J.Biol.Sci.7:633-639.

Shad Khan Khalil; John Mexal; Abdur Rehman; Amanullah; Fida Muhammad and Amir Zaman Khan. 2011. Foliar boron enhances leaf chlorosis and does not affect Pecan production and nut quality, Journal of Plant Nutrition. 34(12): 1811-1819.

Sharma, A. K., Singh, K. and Mishra, S. P. 2002. Effect of foliar spray of zinc sulphate, 2,4.5-T and $\mathrm{GA}_{3}$ on quality of Kagzi lime (Citrus aurantifoliar Swingle). Orissa J. Hort., 30(2):115-118.

Shawky, I., S., El-Shazly, F. A. Ahmed, and S. Awad. 1990. Effect of chelated zinc sprays onmineral connect and yield of Navel orange tree. Annals of Agricultural Sciences, Faculty of Agriculture, Ain Shams University Special Issue: 613-625.

Shekhar, C., Yadav, A. L., Singh, H. K. and Singh, M. K. 2010. Influence of micronutrients on plant growth, yield and quality of papaya fruit (Carica papaya L.) cv. Washington. Asian J. Hort.5 (2): 326329.

Sohrab Davarpanah, Mohammad Akbari, Mohammad Ali Askari, Mesbah Babalar, and Mohammad Esmaeil Naddaf 2013. Effect of iron foliar application (FeEDDHA) on quantitative and qualitative characteristics of pomegranate cv. "Malas e-Saveh". World Sci. J., (04) ISSN 23073071.

Singh, D. K., Paul, P. K. and Ghosh, S. K. 2005. The response of Papaya to foliar application of boron; zinc and their combinations. Research on Crops. 6 (23024): 27.

Singh, P. C., Chaturvedi, O. P. and Mishra, C. N. 2007. Effect of zinc boron and copper on physicochemical characteristics and shelf life of aonla. National Seminar on Management of Medicinal and Aromatic Plants in Farming Systems Prospective 2022 March, 2007. Directorate of extensión
C.S. Azad Uni, Agric, and Tech., (161162).

Singh, P. N. and Chhokar, V. S. 1983. Effect of zinc, boron, and molybdenum as a foliar spray on the chemical composition of guava fruit. Punjab Hort. J., 23 (2/3): 3437.

Singh, R. S. and Vashistha. 1997. Effect of foliar spray of nutrient on fruit drop, yield and quality of ver cv. Seb. Haryana $J$. Hort., Sci., 26 (1-2): 20-24

Sinha, A. K., Singh, C. and Jain, B. P. 1999. Effect of plant growth substance and micronutrients on fruit set, fruit drop, fruit retention and cracking of litchi cv. Purbi. Indian J. Hort., 56 (4): 309-311.

Slowik, K. and Swietlik, D. 1978. Nawozenie polistne roslin sadowniczych. Postepy Nauk Rolniczych 2: 25-44.

Solar, A. and Stampar, F. 2001. Influence of boron and zinc application on flowering and nut set in 'Tonda di Gifoni' hazelnut. Acta Horticulturae. 556: 307.

Sourour, M. M. 2000. Effect of foliar application of some micronutrients forms on growth, yield, fruit quality and leaf mineral composition of Valencia orange trees grown in North Sinai. Alexandria J. Agri. Res.45 (1): 269-285.

Stampar, F., Sturm, K.: Hudina, M. and Usenik, V. 1999. Influence of foliar fertilization on yield quantity and quality of apple (Malus domestica Borkh.). In: Anac, D., MartinPrével, P. (eds.). Improved crop quality by nutrient management. Dordrecht, Kluwer Academic Publishers: 91-94.

Stover, E., Fargione, M., Risio, R., Stiles, W. and Iungerman, K. 1999. Prebloom foliar boron, zinc and urea applications enhance cropping of some 'Empire' and 'McIntosh' apple orchards in New York. HortScience 34: 210.

Usha, K., and Singh, B. 2002. Effect of macro and micro nutrient spray on fruit yield and quality of grape (Vitis Vinifera L.) cv. Perlette. Acta Hort., 594: 197-202.

Valentina Usenik and Franci Stampar, 2007. Acta agriculturae Slovenica, 89 - 1.

Waskela, R. S., Kanpure, R. N., Kumawat, B. 
R. and Kachouli, B. K. 2013. Effect of foliar spray of micronutrients on growth, yield and quality of guava (Psidium guajava L.) cv. Dharidar. International J. Agri. Sci. 9(2):551-556.

Wojcik, P. 1999. Effect of boron fertilization of 'Dabrowicka' prune trees on growth, yield, and fruit quality. Journal of Plant Nutrition. 22: 1651.

Wojcik, P. and Wojcik M. 2006. Effect of Boron Fertilization on Sweet Cherry Tree Yield and Fruit Quality Journal of Plant Nutrition. 29: 1755-1766.

Wojcik, P. and Wojcik, M. 2003. Effect of boron fertilization on 'Conference' pear tree vigor, nutrition, and fruit yield and storability. Plant and Soil. 256: 413.

Yadav and Sharma, P. K. 2009. The foliar application of potassium sulphate on yield and quality of ber (Zizyphus mauritiana
Lamk.) cv. Umran. 25 (1/2): 129-130.

Zagade, P. M., Munde, G. R. and Shirsath, A. H. 2017. Effect of foliar application of micronutrients on yield and quality of Guava (Psidium guajava L.) Cv. Sardar. Journal of Pharmacy and Biological Sciences. 12(5): 56- 58.

Zhang ChengHao Lim YongSup Kang HoMin Kim 1lSeop Korean. 2010. Effect of nutrient solution concentration on the growth and quality of paprika grown by fertigation using waste nutrient solution. Journal of Horticulture Science and Technology. 28:1, 46-50.

Zude, M., Alexander, A. and Ludders, P. 1998. Influence of boron spray in autumn or spring on flower boron concentration, fruit set and yield in apple cv. Elstar. Erwerbsobstbau 40: 18.

\section{How to cite this article:}

Karuna Shanker, Sanyat Misra, Mukesh Topwal and Varun Kumar Singh. 2019. A Research Review on Use of Micronutrient in Fruit Crops. Int.J.Curr.Microbiol.App.Sci. 8(08): 30143025. doi: https://doi.org/10.20546/ijcmas.2019.808.349 